\title{
Correlative 24-hour relationships between intraocular pressure and plasma cortisol in normal subjects and patients with glaucoma
}

\author{
ELLIOT D. WEITZMAN, PAUL HENKIND, MARK LEITMAN, AND \\ LEON HELLMAN \\ From the Departments of Neurology, Ophthalmology, and Oncology, Montefiore Hospital and Medical Center, \\ and the Albert Einstein College of Medicine
}

It has been known for many years that there is a 24-hour cycle of intraocular pressure (IOP) in normal subjects and in patients with glaucoma (Boyd and McLeod, 1964; Drance, 1963; DukeElder, 1952; Ericson, 1958; Katavisto, 1964; Langley and Swanljung, 195I ; Maslenikow, 1904; Thiel, 1925). On the basis of infrequent measurements (generally two to four times per day), the highest pressures have been found in the morning upon awakening and the lowest values in the evening. In a recent report, we described the 24-hour pattern of IOP in normal subjects and in patients with glaucoma with measurements made hourly and, in some cases, every 20 minutes (Henkind, Leitman, and Weitzman, 1973). It was found that the lowest ocular tension occurred between 2 and $4 \mathrm{am}$, with the subsequent rise taking place during the latter third of the night's sleep period.

It has been reported that adrenocorticoids may play a role in the pathogenesis of certain types of glaucoma (Armaly, r 963; Becker, 1967; Bernstein and Schwartz, 1962). The plasma concentration of cortisol in man has also been shown to be at its lowest value during the early part of the nocturnal sleep period and to rise in an episodic manner during the latter half of the night (Boyd and McLeod, r964; Hellman, Nakada, Curti, Weitzman, Kream, Roffwarg, Ellman, Fukushima, and Gallager, 1970; Smith, Stempfel, Campell, Hudnel, and Richman, 1962; Weitzman, Schaumburg, and Fishbein, 1966). We have, therefore, carried out a study correlating the detailed 24-hour temporal relations between IOP and the episodic pattern of cortisol secretion in normal subjects and in patients with different types of glaucoma.

\section{Methods}

Eleven subjects, two normal and nine with various types of glaucoma were studied (Table I). All glaucomatous

Supported in part by funds from PHS EY-or224, OHoo331, CRC-RR 53, and grant from 'Research to Prevent Blindness'

Address for reprints: P. Henkind, MD, PhD, Montefiore Hospital and Medical Center, 1 I I East 2 Ioth Street, Bronx, New York 10467 patients discontinued medication for at least 24 hours before admission to the study unit. Each subject was admitted to a research clinical sleep unit and an adaptation night of normal sleep preceded the 24-hour measurement protocol. On the next morning a small catheter was placed in a vein of the subject's arm and connected to a long catheter $(3 \mathrm{~m})$ filled with heparinized saline and extending to an adjoining room. Individual blood samples were then obtained every 20 minutes for the next 24 hours. After each sample, the tubing was flushed with the saline-heparin solution and discarded before obtaining the succeeding sample. Each blood sample was then centrifuged and the plasma supernatant was rapidly frozen for subsequent hormone assay. This technique has been successfully used in our laboratories for several years and described more fully in preceding publications (Weitzman, Fukushima, Nogeire, Roffwarg, Gallagher, and Hellman, 1971).

A Mackay-Marg tonometer was used to measure the IOP of both eyes every hour for a 24 -hour period.

\section{Table I Population studied}

\begin{tabular}{|c|c|c|}
\hline $\begin{array}{l}\text { Subject } \\
\text { no. }\end{array}$ & $\begin{array}{l}\text { Age } \\
\text { (years) }\end{array}$ & Diagnosis \\
\hline I & 22 & $\begin{array}{l}\text { Pigmentary glaucoma } \\
\text { (both eyes) }\end{array}$ \\
\hline 2 & 20 & $\begin{array}{l}\text { Steroid-induced glaucoma } \\
\text { (both eyes) }\end{array}$ \\
\hline 3 & 25 & $\begin{array}{l}\text { Iridogoniodysgenesis } \\
\text { (both eyes) }\end{array}$ \\
\hline 4 & 26 & $\begin{array}{l}\text { Late congenital glaucoma } \\
\text { (both eyes) }\end{array}$ \\
\hline 5 & 40 & $\begin{array}{l}\text { Open-angle glaucoma } \\
\text { (both eyes) }\end{array}$ \\
\hline 6 & 53 & $\begin{array}{l}\text { Traumatic-angle recession } \\
\text { (left eye) }\end{array}$ \\
\hline 7 & 34 & $\begin{array}{l}\text { Plateau iris glaucoma } \\
\text { (both eyes) }\end{array}$ \\
\hline 8 & 66 & $\begin{array}{l}\text { Chronic open-angle glaucoma } \\
\text { (both eyes) }\end{array}$ \\
\hline 9 & $3 \mathbf{I}$ & $\begin{array}{l}\text { Congenital glaucoma } \\
\text { (both eyes) }\end{array}$ \\
\hline 10 & $4 I$ & Normal \\
\hline I I & 25 & Normal \\
\hline
\end{tabular}


In two patients (nos 3 and 4 ), IOP measurements were taken every 20 minutes from 2 am to 7 am (Henkind and others, 1973). Measurements were obtained without discomfort using one drop of Ophthaine ${ }^{R}$ diluted ten times with $\mathrm{N}$-saline. The average of five acceptable traces was defined as the ocular tension at that time. In several subjects fluorescein was applied to the eye after the pressure had been measured and no damage was found. During the nocturnal sleep period, the subjects were awakened for 5 to 10 minutes for each hourly measurement and in most instances promptly fell asleep again until the next measurement. In one subject (no. r) dexamethasone $(2 \mathrm{mg}$ ) was given intravenously at $7 \mathrm{pm}$ to repeat the 24-hour measurement to determine whether the expected suppression and absence of circulatory cortisol would alter the circadian pattern of IOP.

At the time of going to sleep at night (approximately II pm), standard electrodes were applied and polygraphic sleep recordings were begun using electroencephalographic, electromyographic, and electro-oculographic measurements. The all-night sleep pattern definition was obtained using standard scoring techniques described by the criteria of Rechtschaffen and Kales, I968. The plasma cortisol assay was carried out in our laboratories using a micro-modification of the competitive protein-binding method (Murphy, Engelberg, and Pattee, 1963). A standard curve, background counts, and a known standard were determined for each set of plasma sample measurements. Assays were done in duplicate, and differences greater than ro per cent were repeated in a subsequent analysis.

\section{Results}

TWENTY-FOUR HOUR CORTISOL PATTERN

The 24-hour pattern of cortisol secretion in the patients with glaucoma was compared with that of our previously published groups of normal subjects (see Fig. I and Table II) (Hellman and others, 1970; Weitzman and others, 197I). The mean plasma concentration, total cortisol secreted, minutes spent in secretion, and number of secretory episodes* for the sampled 24-hour period for the glaucomatous patients were not different from the normal group. As the age range of the glaucomatous patient group in this study is comparable to previous cortisol studies (except for patient no. 8) these comparisons can be appropriately made (Weitzman and others, 1971). All subjects secreted cortisol episodically with the mean duration of the inter-episode intervals as a function of time of day also comparable to that previously reported (Table III) (Weitzman, Fukushima, Nogeire, Hellman, Sassin, Perlow, and Gallagher, 1974).

\section{TWENTY-FOUR HOUR IOP PATTERN}

The 24-hour patterns of hourly IOP measurements in this group of patients were also included in the

\footnotetext{
* See Weitzman and others (197I) for description of methods used to obtain this information
}

Table II 24-hour cortisol secretory patterns in glaucomatous patients and normal subjects

\begin{tabular}{|c|c|c|c|c|}
\hline $\begin{array}{l}\text { Subject } \\
\text { no. }\end{array}$ & $\begin{array}{l}\text { No. of } \\
\text { episodes }\end{array}$ & $\begin{array}{l}\text { Total } \\
\text { cortisol } \\
\text { secreted }\end{array}$ & $\begin{array}{l}\text { Total } \\
\text { minutes } \\
\text { spent in } \\
\text { secretion }\end{array}$ & $\begin{array}{l}\text { Mean } \\
\text { concentration } \\
\text { for the } \\
24-h r \\
\text { period }\end{array}$ \\
\hline I & I4 & $2 I \cdot 3$ & 406 & $8 \cdot 9$ \\
\hline 2 & 10 & $23 \cdot 7$ & $44 I$ & $6 \cdot 5$ \\
\hline 3 & 12 & 16.4 & 367 & $5 \cdot 9$ \\
\hline 4 & 9 & 10.6 & 340 & $6 \cdot 2$ \\
\hline 5 & 9 & $25 \cdot 2$ & 339 & $8 \cdot 9$ \\
\hline 6 & I 5 & $27 \cdot 6$ & 473 & $7 \cdot 7$ \\
\hline 7 & 9 & I I'O & 280 & $4 \cdot 3$ \\
\hline 8 & 12 & $24 \cdot 8$ & $45^{6}$ & $9 \cdot 4$ \\
\hline 9 & Io & $28 \cdot 1$ & 477 & $8 \cdot 8$ \\
\hline IO & I I & 23.0 & 465 & $8 \cdot I$ \\
\hline I I & 12 & 18.0 & 429 & $6 \cdot 2$ \\
\hline
\end{tabular}

Table III Mean duration of episodes and interepisode periods of cortisol secretion in glaucomatous patients

\begin{tabular}{lll}
\hline Hours & $\begin{array}{l}\text { Mean duration of } \\
\text { secretion episode } \\
\text { (min) }\end{array}$ & $\begin{array}{l}\text { Interepisode } \\
\text { duration } \\
\text { (min) }\end{array}$ \\
\cline { 2 - 3 } $8 \mathrm{pm}-2$ am & 35 & I3I \\
2 am-8 am & 33 & $9 \mathrm{I}$ \\
8 am-2 pm & 37 & I43 \\
2 pm-8 pm & 34 & I65 \\
\hline
\end{tabular}

results for the subject group recently reported in a brief communication (Henkind and others, 1973). The mean IOP in the nine glaucomatous patients ranged from a minimum of $16 \mathrm{~mm} \mathrm{Hg}$ at 3 am to a peak of $27 \mathrm{~mm} \mathrm{Hg}$ at II am and noon. However, there was considerable variability in the amplitude difference across subjects; the greatest difference between the low and high value in one subject was $3 \mathrm{I} \mathrm{mm} \mathrm{Hg}$ (no. 7). It is important to emphasize that in each patient the pressure dropped to $19 \mathrm{~mm}$ $\mathrm{Hg}$ or less, during sleep even when pressures were $30 \mathrm{~mm} \mathrm{Hg}$ or greater during the day (Figs I and 2).

In addition to the wide 24-hour amplitude ranges, there were significant hour-to-hour changes in pressure. There were 22 times (out of a possible 350) when a rise or fall of more than $6 \mathrm{~mm} \mathrm{Hg}$ occurred in the sequential hour-to-hour measurements. Of the 15 rises in IOP greater than $6 \mathrm{~mm} \mathrm{Hg}$, I3 occurred between 2.30 am and 9.30 am, whereas six of the seven falls in IOP greater than $6 \mathrm{~mm} \mathrm{Hg}$ occurred between I pm and $2 \mathrm{am}$. In the two patients who were measured every 20 minutes 


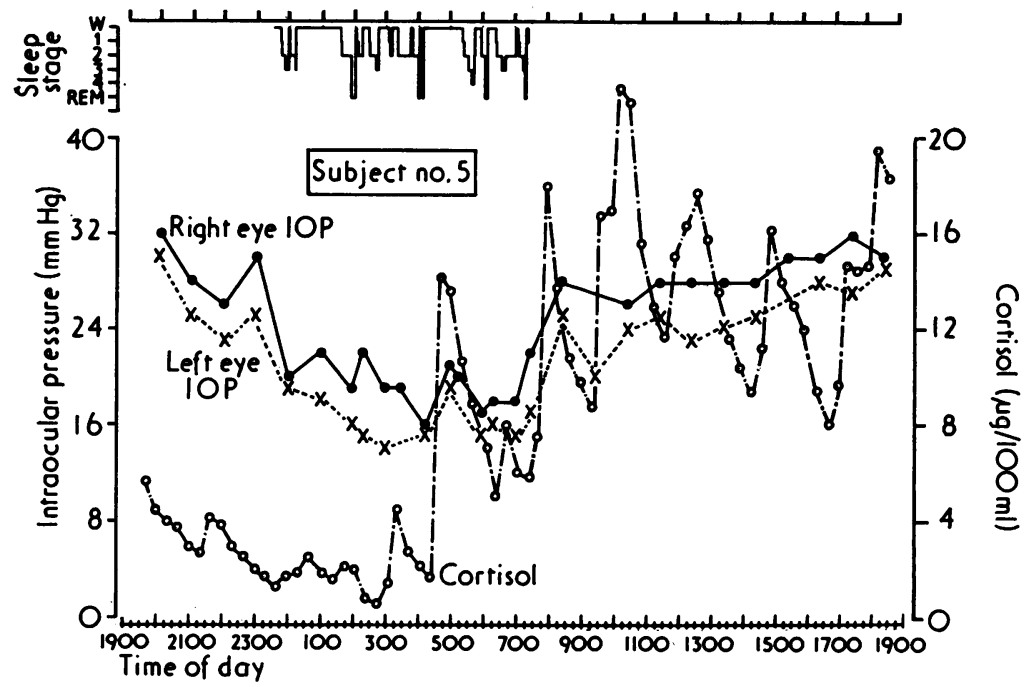

FIG. I 24-hour plot of plasma cortisol concentration sampled every $20 \mathrm{~min}$. Included are IOP for both eyes measured every hr and sleep stage patterns during night (subject no. 5) during sleep, pressure increments equal to, or greater than, $6 \mathrm{~mm} \mathrm{Hg}$ occurred on three occasions. A pressure increment of $6 \mathrm{~mm} \mathrm{Hg}$ occurred from 3.30 am to 3.40 am for patient no. 3 (Fig. 2) and a rise of 10 and $6 \mathrm{~mm} \mathrm{Hg}$, respectively, occurred at $2.20 \mathrm{am}$ to $2.40 \mathrm{am}$ and $6.00 \mathrm{am}$ to $6.20 \mathrm{am}$ for patient no. 4.

A 24-hour curve of IOP was obtained for each of the patients and normal subjects (Figs 3 and 4). When the mean 24-hour pressures are plotted separately for the glaucomatous eyes and the normal eyes and expressed as a percentage deviation about the 24-hour mean value, the two curves are essentially identical and superimposable (Fig. 4).
The lowest value of the 24-hour pressure curve in each case occurred between $I$ and 4 am for the glaucomatous eyes, in spite of the varied diagnoses.

We have confirmed previous reports indicating that the temporal pattern of IOP change is remarkably parallel in the two eyes (Duke-Elder, 1952; Ericson, 1958; Kollner, I916, 1918a, I918b, I921). When the pressure in one eye rose by $5 \mathrm{~mm}$ or more during the next hour on 15 occasions, for 13 of these, the other eye showed a concomitant rise in pressure. The pressure fell $5 \mathrm{~mm}$ or more during an hour on nine occasions and on seven of these the other eye also showed a fall in pressure. This occurred not only when bilateral glaucoma
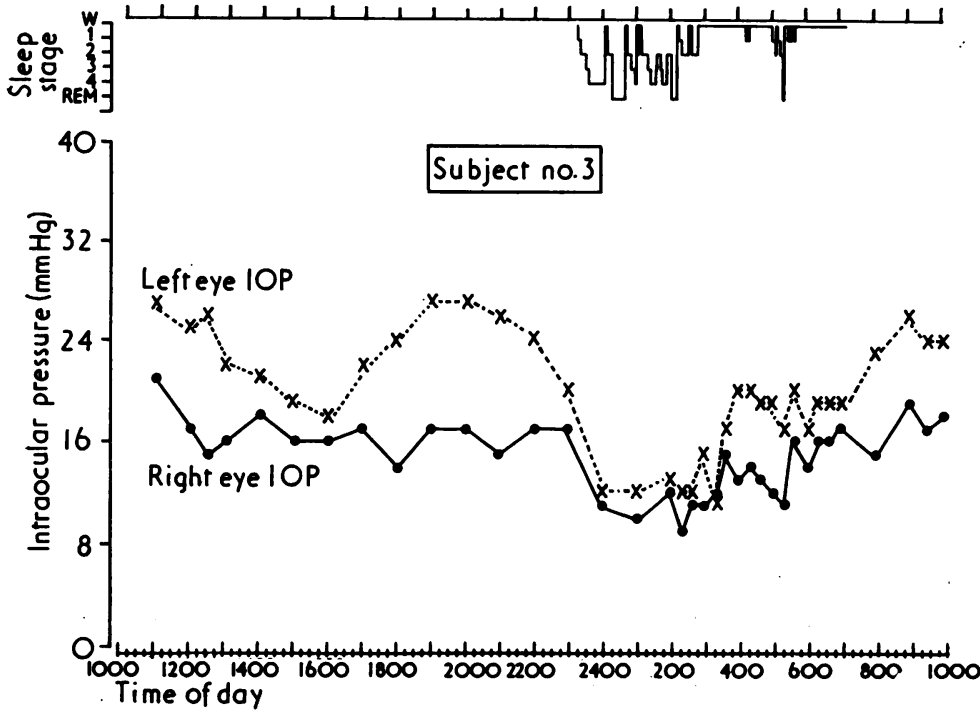

FIG. 2 24-hr plot of IOP in both eyes measured every 20 min from 0200 to 0700 and every $\mathrm{I} h \mathrm{hr}$ for rest of $24-\mathrm{hr}$ period (subject no. 3) 


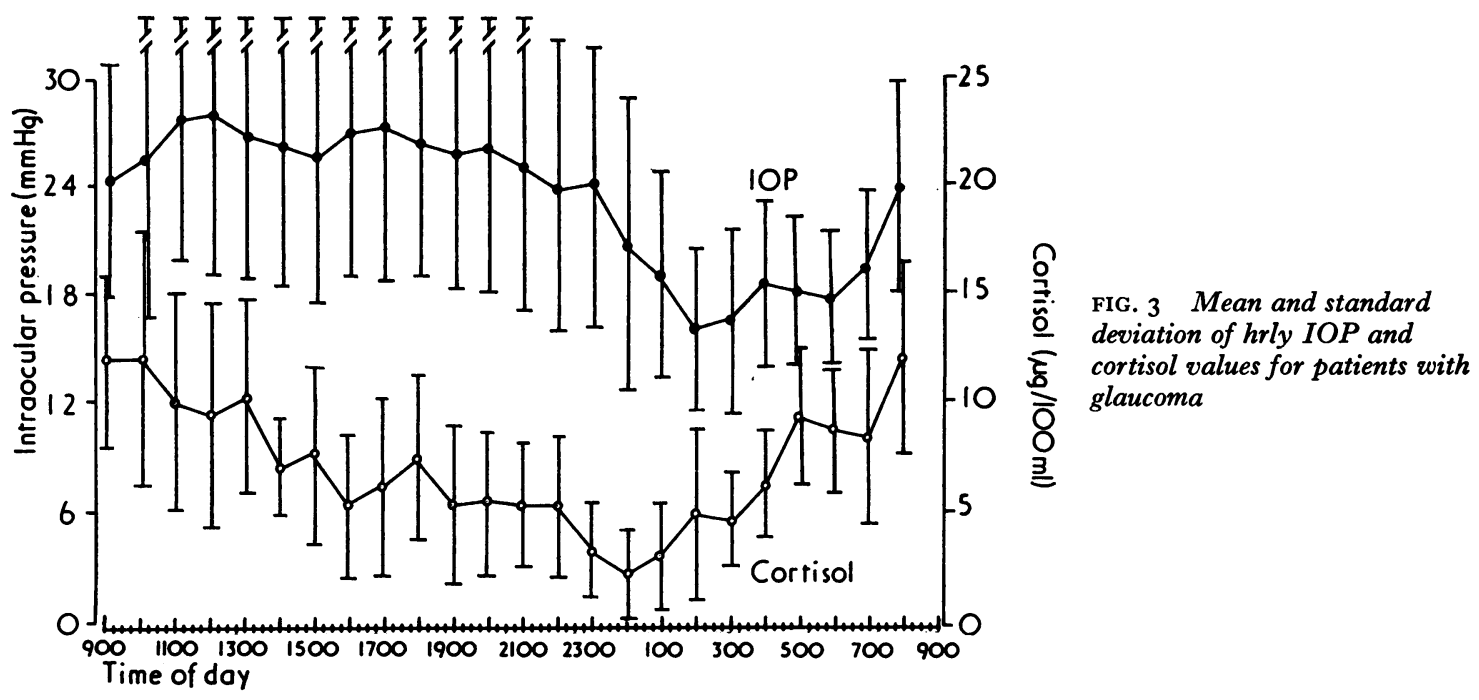

was present, but also when one eye was normal and the other eye had a raised IOP. In the two normal subjects a similar parallelism in short-term pressure changes was apparent between the two eyes.

\section{CORRELATION BETWEEN 24-HOUR CORTISOL AND IOP CURVES}

There was a phase difference of 3 hours between the mean nadir and peak of the IOP and cortisol 24-hour curves (Fig. 4). The plasma cortisol concentration curve preceded the IOP curve for both glaucomatous and normal eyes. The time differences for the maximum and minimum values of

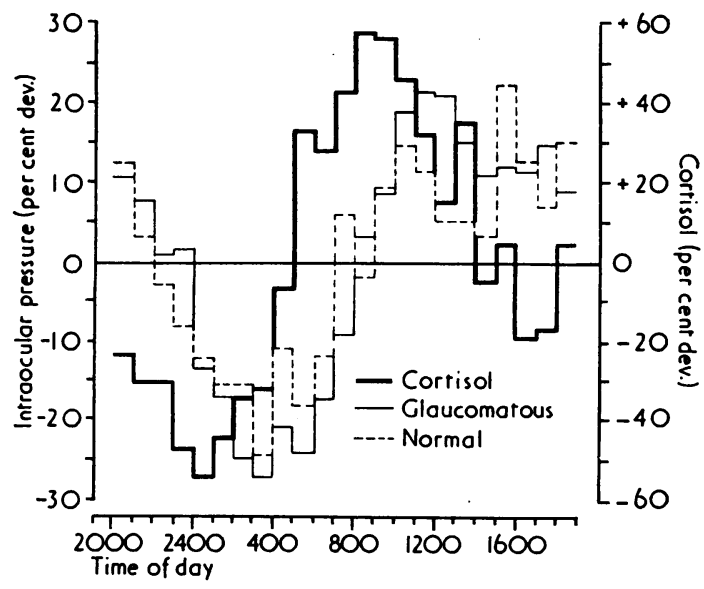

FIG. 4 Relationship between mean 24-hr curves of cortisol and IOP in normal and glaucomatous eyes. Plots are expressed as percentage deviation about mean 24-hr values. (Percentage deviation scale is doubled for $I O P$ ) the amplitude of both the cortisol and IOP curves are the same ( 8 hours rising from minimum to maximum and 16 hours falling from maximum to minimum). Therefore, the curve shapes are not sinusoidal but are both positively skewed with a 'form factor' of 2.0 (Wever, 1973). By inspection it is clear that, when a 3 -hour phase shift is carried out, the maxima and minima of the two curves are superimposed (with correction of the amplitude of the percentage deviation between the two variables) (Fig. 5). The shape of the curves from approximately 3 hours before the minimum value to approximately 3 hours after the maximum value is essentially identical. However, the other portion of the two curves, primarily on the decreasing side, diverges in form so that the average cortisol concentration falls rapidly whereas the IOP tends to rise and then to remain at values above the mean until it falls to a minimum value during sleep. It is therefore accurate to speak of a phase-shift difference in circadian rhythm only during the portions of the two curves which have the same form (Wever, 1973). It is certainly not surprising that there is a divergence in the shape of the two curves during part of the 24 hours for such different physiological systems. This difference in the falling portion suggests that the mechanisms may have different time courses. However, the remarkable superimposition of the duration and the form of the rising portion of the two mean curves raises the possibility that a common mechanism may be coupled to both systems during this period of the day.

In one subject (no. I), with bilateral pigmentary glaucoma, $2 \mathrm{mg}$ dexamethasone was given intravenously at $7 \mathrm{pm}$ for a repeat 24 -hour measurement period to determine whether the suppression and absence of circulating cortisol would alter the 24- 


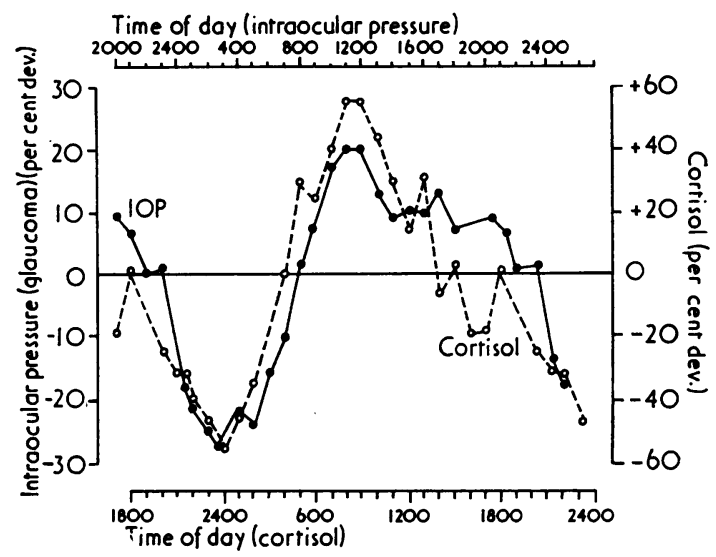

FIG. 5 Relationship of 24-hr IOP and cortisol curves when plotted with a phase shift of $3 \mathrm{hr}$ (derived from Fig. 4)

hour pattern of IOP. Plasma samples were again obtained every 20 minutes and IOP was measured every hour for a 30 -hour period (from $5.25 \mathrm{pm}$ on Day I to $10.40 \mathrm{pm}$ on Day 2). It was found that, in spite of total suppression of cortisol secretion and, therefore, of the absence of a circadian plasma cortisol influence, the circadian IOP curve was still present, with the nadir and peak occurring at essentially the same time as in the preceding baseline 24-hour period (Fig. 6).

\section{SLEEP STAGE PATTERNS}

The nocturnal sleep stage patterns defined polygraphically are outlined in Table IV. Because of the hourly awakening for IOP measurements during the night, the subjects had a total mean amount of sleep of 4 hours and 44 minutes during the night. The sleep stage percentage distribution within that decreased total sleep time, however, was not very abnormal with the exception of rapid eye movement (REM) sleep (Table IV). This sleep stage was reduced to I I per cent compared with the expected normal range of i 5-20 per cent of total sleep time for the comparable age group studied (Williams and Karacan, 1964).

\section{Discussion}

There has been considerable interest in the relationship between adrenocortical steroids and intraocular pressure changes. It has been known for some time that there is a correlative temporal relationship between the circadian pattern of IOP and blood cortisol concentrations (Smith and others, 1962). Although several reports have suggested that the cortisol rise at night might produce the rise in IOP at that time, there has never been

Table IV Waking and sleep patterns during the night in subjects studied with 24-hour IOP and cortisol measurements

\begin{tabular}{|c|c|c|c|}
\hline \multirow[b]{2}{*}{ Time } & \multirow{2}{*}{$\begin{array}{l}\text { Mean time } \\
(\min )\end{array}$} & \multicolumn{2}{|l|}{ Percentage } \\
\hline & & Total time & Sleep \\
\hline Total & 478 & & \\
\hline $\begin{array}{l}\text { Waking } \\
\text { Sleep }\end{array}$ & $\begin{array}{l}194 \\
284\end{array}$ & $40 \cdot 6$ & \\
\hline Total & & & \\
\hline Stage I & $\begin{array}{r}28 \\
158\end{array}$ & $\begin{array}{r}5 \cdot 8 \\
33 \cdot 2\end{array}$ & $\begin{array}{l}10.2 \\
56.2\end{array}$ \\
\hline $\begin{array}{r}3 \\
4\end{array}$ & $\begin{array}{l}27 \\
38\end{array}$ & $\begin{array}{l}5 \cdot 6 \\
7 \cdot 8\end{array}$ & $\begin{array}{r}9.4 \\
12.9\end{array}$ \\
\hline REM & 33 & $7 \cdot 0$ & $11 \cdot 3$ \\
\hline
\end{tabular}
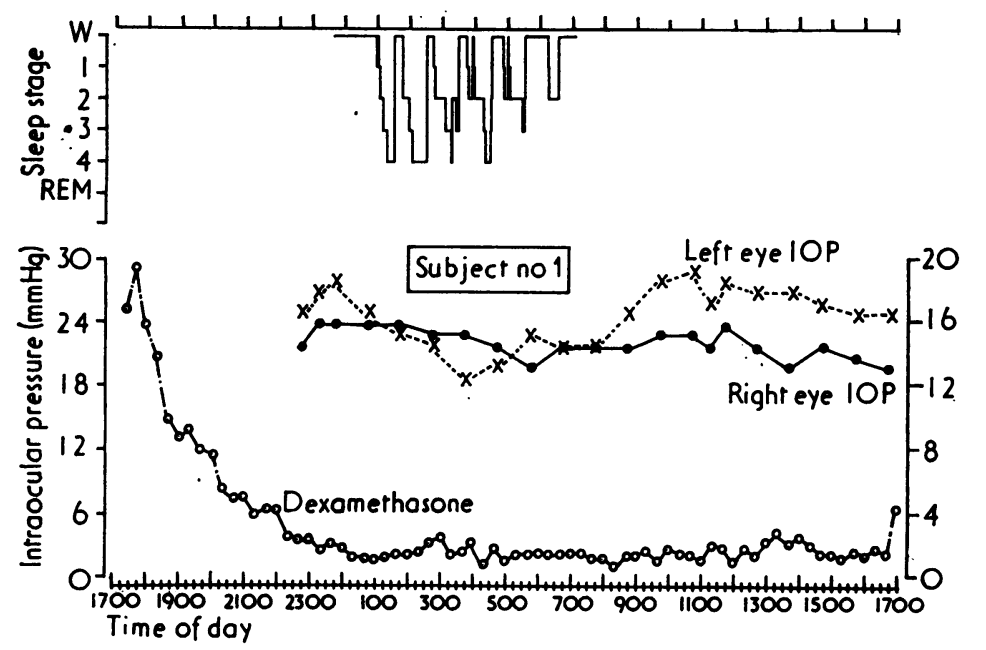

FIG. 6 24-hr plot of IOP and plasma cortisol concentration in subject no. I after administration of $\underset{<}{0}$ dexamethasone (2 mg intravenously at 2000). Circles represent IOP right eye, triangles represent IOP left eye. A 24-hr curve of IOP is present although cortisol is suppressed 
a clear demonstration of such a causal relationship (Boyd and McLeod, 1964; Linner, 1959; Weinstein and Mori, 1972). There is evidence that topically applied corticosteroids in repeated dosage and high concentrations over several weeks produce an abnormal rise in the IOP in the glaucoma range, and that, if this treatment is stopped, the IOP usually returns to normal (Armaly, 1963; Becker, 1967; Bernstein and Schwartz, 1962; Bigger, Palmberg, and Becker, 1972; Schwartz, 1966). In addition, several cases of Cushing's syndrome have been reported to have high IOP values. Circadian measurements, however, have not been studied in these patients (Haas and Nootens, I974; Neunar and Dardenne, 1968).

In this paper we have described the detailed temporal relationship between 24-hour IOP and plasma cortisol and have clearly shown a high degree of temporal correlation between the two, with a phase difference of 3 hours. These results are in esssential agreement with Boyd and McLeod's report of a 4 -hour phase difference between the maximum IOP and maximum plasma corticoid values when a 4 -hour sampling interval was used. Our findings of a 3 -hour phase difference at the time of minimum values, however, does not agree with their conclusion that both curves reached a minimum at the same time, midnight (Figs 4 and 5). This difference may well be due to the use of more frequent sampling carried out in the present study. Schwartz and Levene (1972) measured a single plasma cortisol concentration between 8 am and noon in patients with glaucoma and compared the results with those in a group of normal subjects. They reported a higher median cortisol value in the glaucoma group ( 16 to $17 \mathrm{mg}$ per cent), compared with the normal group (12.7 mg per cent). Our data, however, do not show a difference when the mean value of all cortisol samples ( 12 per subject) taken between those times in the glaucomatous patients (10.2 mg per cent) are compared with a normal group of comparable age $(10 \cdot 2 \mathrm{mg}$ per cent). The differences found by Schwartz and Levene may be due not only to differences in the technique of obtaining the plasma sample, but also to the considerable variability of plasma cortisol concentration which is due to the pattern of episodic secretion. Therefore, all studies in which a single or even infrequent sampling is carried out will have the same problem (Das and Hitchings, 1971).

Boyd and McLeod administered an II-beta hydroxylase inhibitor (metapirone SU-4885) given intravenously to block the production of cortisol from the adrenal cortex and measured the IOP response. They reported that it 'was followed by interruption of the rising phase of IOP and that the subsequent falling phase occurred at pressure levels lower than during the control period'.
Measurements were made only every 4 hours during a time of day when there is considerable variability in IOP values. The lack of change in the 24-hour IOP curve in both eyes in our patient when cortisol secretion was totally suppressed by dexamethasone suggests that the temporal phase relationship between cortisol and IOP may be only correlative and not causative. Further studies are clearly needed and are currently being undertaken in our laboratories.

The results of this study as well as those of previous studies support the concept that one or more systemic factors control the temporal changes in IOP. The clear synchrony between the two eyes and among the subjects suggests that the mechanisms involved in producing the normal daily pressure rise are the same as those that produce the short-term as well as the 24-hour exaggerated increments in glaucoma of differing aetiologies.

The present data suggest that the major rise in IOP in various types of glaucoma which takes place during the latter part of the sleep period and extends into the morning waking time is essentially an exaggeration of the normal pattern of IOP present at this time of the day. If this concept is correct, then the discovery of the mechanisms underlying the normal circadian rise in IOP may lead to the development of more rational therapeutic methods for controlling the raised IOP in patients with glaucoma.

The possibility of a circulating substance controlling the changes in IOP is supported by the study of Stone and Sears (1959). They cross-circulated two rabbits and produced a significant fall in IOP in ore animal's eye when they compressed the other animal's eye. In human and animal studies several hormones in addition to cortisol have been shown to affect IOP. These include: prostaglandin (Chiang and Thomas, 1972; Waitzman, 1970; Wyllie and Wyllie, I97I), aldosterone (Frenkel and Krill, 1964), oestrogen (Meyer, Roberts, Liebowitz, McGowan, and Houle, 1966), thyroxine (Pohjanpelto, 1968), catecholamine (Gloster and Greaves, 1958; Holland and Mims, 1971; Langham, I97I), ADH (Ikeda, Tanabo, and Uno, 1963), as well as cortisol. Other factors considered have been plasma $\mathrm{pH}$ (Bietti, 1972), blood pressure (Weigelin, 1972), and serum osmolality changes (More, 1970). In a recent review, Waitzman (I97I) concluded that the hypothalamus might be the major central nervous system controlling site for changes in IOP. Certainly the 24 -hour correlative relationships with differing hypothalamic controlled circadian events, such as neuroendocrine processes, body temperature, sleep-waking functions, autonomic activity, etc., would support that this central nervous system area may be critically involved (Conroy and Mills, 1970). 


\section{References}

ARMALY, M. F. (rg63) Arch. Ophthal., 70, 482

BECKER, B. (1967) Topical corticosteroid and intraocular pressure, in 'Current Concepts in Ophthalmology', p. 132. Mosby, St Louis BERNSTEIN, H. N., and SCHWARTZ, B. (1962) Arch. Ophthal., 68, 742 BIETTI, G. (1972) Amer. F. Ophthal., 73, 475 BIGGER, J. F., PALMBERG, P. F., and BECKER, B. (1972) Invest. Ophthal., II, 832 BOYD, T. A. S., and MCLeOD, L. E. (1964) Ann. N.Y. Acad. Sci., II7, 597 CHIANG, T. S., and THOMAS, R. P. (1972) Invest. Ophthal., 11, 169 CONROY, R. T. W. L., and MILls, J. N. (1970) 'Human Circadian Rhythms'. Churchill, London DAS, S. N., and HITCHINGS, R. A. (197I) Trans. ophthal. Soc. U.K., 91, 749 DRANCE, S. M. (1963) Arch. Ophthal., 70, 302 DUKE-ELDER, s. (1952) Amer. F. Ophthal., 35, I ERICSON, L. A. (1958) Acta ophthal. (Kbh.), (Suppl.) 50 FRENKEL, M., and KRILL, A. E. (1964) Arch. Ophthal., 72, 315 GLOSTER, J., and GREAVES, D. P. (1958) Brit. F. Ophthal., 42, 385 haAs, J. S., and nootens, R. H. (1974) Amer. F. Ophthal., 78, 497 HELlMAN, L., NAKADA, F., CURTI, J., WEITZMAN, E. D., KREAM, J., ROFFWARG, H., ELlMAN, S., FUKUSHIMA, D. K., and GALLAGHER, T. F. (1970) Ү. clin. Endocr., 30, 4I I HENKIND, P., LEITMAN, M., and WEITZMAN, E. D. (1973) Invest. Ophthal., 12, 707 HOLLAND, M. G., and MIMS III, J. L., (1971) Ibid., I0, 120 IKEDA, I., TANABO, Y., and UNO, Y. (1963) Folia ophthal. jap., 14, 516 katavisto, м. (1964) Acta ophthal. (Kbh.), (Suppl.) 78 KOLlNER, H. (1916) Arch. Augenheilk., 81, 120

(1918a) Ibid., 83, 135

(1918b) Münch. med. Wschr., 65, 229

- (192 I) Arch. Augenheilk., 88, 58

LANGham, M. E. (1971) Proc. roy. Soc. Med., 64, 622

LANGLEY, D., and SWANLJUNG, H. (195I) Brit. $\mathcal{Y}$. Ophthal., 35, 445

LINNER, E. (1959) Trans. ophthal. Soc. U.K., 79, 27

MASLENIKOW, A. Z. (I904) Augenheilk., II, 464

MEYER, E. F., ROBERTS, C. R., LIEBOWITZ, H. M., MCGOWAN, B., and houle, R. E. (1966) Arch. Ophthal., 75, 77 I MORE, B. M. (1970) Brit. F. Ophthal., 54, 554

MURPHY, B. P., ENGELBERG, w., and PATTEE, C. J. (1963) F. clin. Endocr., 23, 293

NeUnar, N. P., and Dardenne, U. (1968) Klin. Mbl. Augenheilk., 152, 570

POHJANPElto, P. (1968) Acta ophthal. (Kbh.), (Suppl.) 97

RECHTSChafFEN, A., and kAlEs, A. (r968) 'A Manual of Standardized Terminology, Techniques and Scoring System

for Sleep Stages of Human Subjects', Publication No. 204, Government Printing Office, United States Public

Health Service, Washington, DC

SCHWARTZ, B. (1966) Int. Ophthal. Clin., 6, 929

SCHWARTZ, B., and LEVENE, R. z. (1972) Arch. ophthal. (Kbh.), 87, 369

SMITH, J. L., STEMPFEL, R. S., CAMPELl, H. S., HUDNEL, A. B., and RICHMAN, D. W. (I962) Amer. F. Ophthal., 54, 4I I STONE, H. H., and SEARS, M. L. (1959) Docum. ophthal. (Den Haag), 13, 147

THIEL, R. (1925) Arch. Augenheilk., 96, 331

WAITZMAN, M. B. (1970) Surv. Ophthal., 14, 301

$$
\text { (1971) Ibid., 16, I }
$$

WEIGELIN, E. (1972) Canad. F. Ophthal., 7, 230

WEINSTEIN, P., and MORI, E. (1972) Klin. Mbl. Augenheilk., 16r, 277

Weitzman, E. D., FUKushima, D., NOGEIRE, C., HEllmaN, L., SASSin, J., PERlow, M., and Gallagher, T. F. (I974)

'Studies on Ultradian Rhythmicity in Human Sleep and Associated Neuroendocrine Rhythms'. Chronobiology Igaku Shoin, Tokyo

\footnotetext{
$\longrightarrow$ - $\longrightarrow$, ROFFWARG, H., GAllaGher, T. F., and hrllman, L. (1971) Ibid., 33, I4

WEVER, R. (1973) Int. $\mathcal{F}$. Chronobiology, I, 371

WILLIAMS, R., and KARACAN, I. (1964) 'EEG of Human Sleep', Wiley, New York

WYLlie, A. M., and WYllie, J. H. (1971) Brit. med. $\mathcal{F} ., 3,615$
} 